\title{
Philanthropy in Public Libraries: Its Impact on Community Well-Being Missions
}

\author{
Kathryn Dilworth ${ }^{1}$ (B)
}

Received: 25 September 2020 / Accepted: 28 June 2021 / Published online: 9 August 2021

(c) The Author(s), under exclusive licence to Springer Nature Switzerland AG 2021

\begin{abstract}
Public libraries support community well-being missions related to access to information, knowledge creation, public service programming and social cohesion. Interviews in this study were designed to discover whether philanthropy in the form of giving positively impact their ability to deliver these missions. Four public library directors in Mississippi were selected for this study because the state reports low community well-being measures and high charitable giving. Findings suggest that philanthropy is a fundamental partner in community well-being missions for these libraries even though, as a sector, public libraries measure low in philanthropic support.
\end{abstract}

Keywords Philanthropy · Fundraising · Volunteering · Public library · Community well-being

Public libraries are community assets with specific goals related to community wellbeing. This study examines the role of philanthropy in achieving those goals. Defining philanthropy, however, is critical to this discussion and emerged in this study as a factor in successfully leveraging philanthropy for community well-being missions. The classic definition of philanthropy is a private action taken in support of a public good (Payton, 1988). This comes out of a tradition of charity as a virtue, first defined by Aristotle (Aristotle \& Irwin, 1999) as generosity, munificence, and magnanimity. This concept was reinterpreted eight hundred years later by Thomas Aquinas as Christian charity (1225-1274) and remains a popular definition within religious traditions. However, the contemporary practice of philanthropy is often interchanged with the term fundraising. In this case, practitioners will use both terms to mean the same thing: fundraising and giving. When commenting on its effectiveness, the former president of the William and Flora Hewlett Foundation defined philanthropy as an outcome of giving that has specific goals Brest, 2012). Others define it as an act

Kathryn Dilworth

kfdilwor@iu.edu

1 Indiana University Purdue University Indianapolis (IUPUI), Indianapolis, IN, USA 
performed by an institution (Gross, 2002) and an instrument (Hall, 1992). Outside the field of practice and scholarship, philanthropy is usually associated with a higher calling to do good in the world while fundraising has a reputation for being more transactional and often aligned with sales (Bartlett, 2018).

This study is interested in exploring philanthropy as a mechanism to build community assets, which is the function of institutional philanthropy. The study goal is to investigate the efficacy of institutional philanthropy in meeting community wellbeing missions of nonprofit organizations. However, defining philanthropy more precisely is necessary to having a discussion about its impact. The lack of a standard concept and use of the term philanthropy had an effect on whether or not public library directors in this study embraced it as a mechanism for meeting community well-being goals. To clarify, in this study, the term philanthropy specifically relates to activities associated with fundraising (asking for donation) and giving (donating) to public libraries.

Philanthropy and community well-being are related because supporting community well-being is often a motivation for giving. In this relationship, philanthropy is a tool for nonprofit organizations to build community well-being. To demonstrate that relationship, this study looks at how philanthropy impacts the ability of public libraries to meet their community well-being goals. Community well-being goals for public libraries are traditionally related to literacy and access to information, but public library missions have expanded in recent years to include goals around community engagement, lifelong learning, and personal and professional growth of the individuals it serves (ALA, 2015). Examples of institutional philanthropy include giving from foundations, individuals, and corporations. Friends of the Library groups and library foundations are often a mechanism for fundraising and facilitating philanthropic support.

Public libraries in the state of Mississippi were selected for this study because Mississippi regularly scores low on well-being scores. The latest Gallup poll on well-being ranked Mississippi in the bottom ten in the country (Witters, 2019). At the same time, Mississippi is regularly named as the most generous state in terms of percentage of income donated to charity (Fuss \& Palacios, 2019). Considering the explicit mission of public libraries to benefit community well-being, the apparent need for support for community well-being in the state of Mississippi, and the fact that philanthropy is popular among its citizens, Mississippi public libraires emerged as a suitable environment to test the impact of philanthropy on community well-being.

\section{Philanthropy - Fundraising and Giving}

Motivations for giving vary depending on an individual's life experience and moral framework. Moral and ethical frameworks are unconsciously functioning in the practice of philanthropy. Ideologies that grow out of Aristotle's concept of virtue, Kant's sense of individual duty and utilitarian views developed through exposure to a market society are in play at fundamental levels in varying degrees depending on the individual taking or receiving action. In a practical sense, these frameworks are 
the foundation for the motivation behind the goals and work in the sector. They also influence decisions around philanthropic giving and the expectations of that giving.

Contemporary philanthropy in America was influenced by British philanthropy, particularly that of the Victorian era. However, it was the philanthropy of the Industrial Age that truly transformed acts of benevolence to an institution for social change (Hall, 1992). Major philanthropists at this time went from seeing philanthropy as a way to mitigate suffering to a tool to impact mankind (Zunz, 2012). One of the Titans of this age was Carnegie who used the public library as a vehicle for the change he wanted to see in American society. Though men like Carnegie earned their wealth through often ruthless business practices, Hall (1992) defends his philanthropy as the result of his awareness of the impact the age had on common people and a sincere desire to provide remedies for their suffering.

The business of philanthropy is what supports and shapes the missions of the nonprofit sector. Most of this support comes from individual donors. Of the $\$ 449.64$ billion in charitable donations contributed to nonprofit organizations in $2019,79 \%$ came from individuals. Corporations and foundations contributed $13.4 \%$ and $17 \%$ respectively to the sector (Giving USA, 2020). To achieve the outcomes of philanthropy, organizations engage in fundraising. This professional practice is facilitated by fundraisers whose job it is to bridge the mission of an organization to donors. Carnegie's impact on public libraries persists in the minds of many donors who continue to see the library as a meaningful organization for their philanthropic support. However, use of public libraries continues to decline (Albanese, 2020), which does not bode well for the future of philanthropic funding to these organizations.

Though the fundraising numbers reported in the annual Giving USA report demonstrate increased giving to the nonprofit sector each year, philanthropic giving to the nonprofit sector is small compared to the role of government funding. Government funding makes up around $80 \%$ overall (Carter et al, 2019). This funding is integral to the success and survival of many nonprofit organizations, particularly those with a social service mission. For public libraries, government support is crucial to meeting their community well-being missions. As interviews with public library directors in this study reveal, the dependance on the support of government funding can sometimes be a barrier to the pursuit of philanthropic support.

\section{Government Funding vs Philanthropy}

Government funding is a major factor in discussions about philanthropy in public libraries across the country because it is common for public libraries to be directly connected to local government budgets. Several factors contribute to a sector-wide hesitancy to patriciate in philanthropic activity, according to Patrick Sweeny, the political director for EveryLibrary (Personal communication, August 13, 2020). The first is a fear about disrupting the reliable, annual funding provided by government funders. There is some evidence that government funding crowds out philanthropic giving as taxpayers see their tax contributions as a contribution to community organizations. However, government funding also seems to decrease fundraising efforts (Andreoni \& Payne, 2003). 
A study on public library funding in the state of Illinois determined that nearly all that state's public libraries rely on income besides their government funding which is tied to tax revenues (Schatteman \& Bingle, 2015). By investigating income from Friends of the Library and Library Foundations, the study was able to demonstrate that despite very few resources to engage in fundraising, most of the libraries in their study were dependent on philanthropic support. Specifically, those donations arrived most often in the form of gifts from individuals. The authors identified a need for governments to consider the role of donations in supplementing tax-generated income. Concern about the risk of reduced government funding due to successful fundraising was voiced by many of the library directors in this study. However, Schatteman and Bingle were more concerned about the opposite: the risk of public goods becoming quasi-public goods when government funding is leveraged for private donations.

Library directors in this study expressed concern that successful fundraising could result in decreased funding from government funders. They also worried about the power that donors might have over their activities and collections. Further, they expressed a general discomfort with the practice of fundraising. However, despite a hesitancy and little focus on fundraising, this study was interested in determining if high rates of philanthropic giving in the state of Mississippi translated to significant giving to public libraries in the state, none-the-less.

\section{Public Libraries}

Interviews with library directors in this study investigated how philanthropy impacts their ability to meet their community well-being missions. Public libraries were selected because their mission is grounded in community well-being. The American Library Association defines the mission of the public library, "to provide leadership for the development, promotion and improvement of library and information services and the profession of librarianship in order to enhance learning and ensure access to information for all" (1876). This mission takes a variety of forms in public libraries across the country depending on the needs of their community. Aabo describes the value of the public library in terms of its alignment with community needs when she explains,

How the role is defined is decided by choice of values, understood as values the libraries are meant to uphold and further - namely cultural, educational and democratic values. The value of public libraries, in the sense of how valuable (e.g. important and significant) they are to citizens communities and in the sense of their monetary worth, is dependent upon how well they perform their role, and how important this role is seen to be in relation to other social values. (2005, p.209)

Digital resources and tools have had a strong impact on the value of the library as a community asset. Once thought to be a harbinger for the death of libraries, the Internet and digital assets have made the library more valuable than ever. An study examining the impact of the Internet on library use discovered that it complemented 
traditional library services. Users who visited the library to get access to the Internet, tended to utilize other library resources and services, and those who came for traditional services often utilized the Internet while there (D'Elia et al, 2002). Data on the impact of the Internet on library services and community impact has demonstrated the degree to which the digital age has increased the value of the public library. However, there is a cost to this positive impact. Public libraries struggle to meet the need for this access (Bertot et al., 2008). Jaeger and Fleischmann (2007) explain that this access has actually created new professional roles in the library which they define as social roles. Further, these social roles have been widely expected and taken on as a fundamental mission and unique service by information professionals, which, combined with the ongoing needs of fresh technology, increase the cost of delivering library services.

Kerslake and Kinnel (1997) define the library's role in well-being in three ways: economic, political and social. Outcomes of that well-being value include employment and wages that support tax income, taking part in civil society through voting and political engagement and coming together as community members to share resources and build relationships (p. 12). A new strategic plan developed by ALA (2015) supports other intangible missions including access to information, public spaces and an environment of tolerance and service. Support for education, access to information, entertainment, and social opportunities are examples the library's contribution to individual and community well-being. Many participate in efforts to support the homeless populations, community health and wellness, and literacy. Libraries are the only places where many individuals have access to the Internet. Librarians routinely assist patrons in submit applications for public assistance and employment. Because of all the ways they support needs across the community, it is common for chambers of commerce to include information about public libraries in their recruitment materials. Public libraries see themselves as social justice advocates through their mission to provide community access to information and information literacy, the skillset required to interrogate and judge the value and relevance of online information. As an association, The American Library Association advocates on behalf of public policy that relates to intellectual freedom, literacy, privacy, public awareness, and equity.

In an effort to quantify the impact of public libraries on community well-being, the Institute of Museum and Library Services in partnership with the Chief Officers of State Library Agencies is currently engaged in a three-year study that looks at the role that public libraries have on community well-being as well as workforce development (Jaros, 2019). This study hopes to provide evidence of the value of public libraries for communities. Previous studies have reported that ninety percent of Americans claim that libraries are important to communities but funding to support them is declining (National Public Radio, 2013). Between 2006 and 2017, only \$2.9 billion in private funding was recorded (Tkacik, 2017). Advocacy organizations like EveryLibrary are working to help public libraries build voter support for municipal funding. The Foundation Center has produced a visualization tool to help libraries discover opportunities for support from philanthropic foundations. With more public libraries in the US than McDonalds or Starbucks, \$2.9 billion over eleven years for libraries when the US averages over $\$ 400$ billion a year is not very much. Nor does 
it seem like much when you consider that over a billion people visit public libraries in a single year (IMLS, 2020).

The Trump administration, for the fourth year in a row, pushed to eliminate all federal funding for libraries. Both EveryLibrary (2020) and the American Library Association (1892) have called on their supporters to help them protect this crucial funding. Like the public libraries featured in this study, most of funding to public libraries comes from the local municipalities they serve. For systems with multiple branches, that can include a city, county, and several small towns. Many public libraries, like the ones in this study, are municipal agencies, themselves. This status is a challenge to fundraising activities though many public libraries create 501c3 organizations that provide the opportunity to pursue charitable donation. However, a hesitation to fundraise permeates the library sector. Confusion about legal and tax implications, consequences of fundraising and a general discomfort with solicitation of gifts are reasons that public libraries often lack robust philanthropy programs even though this income would support innovation and customized service and resources to meet community well-being missions.

At the time of this study, public libraries across north America were closed due to the pandemic. This challenged their ability to meet their community mission. With a history of providing fundamental needs during crisis, their inability to engage either in person or virtually with the community was a legacy of decreased funding and resulting austerity. A recent study of public libraries in the United Kingdom (Hitchen, 2019) demonstrated how austerity as a condition had transformed into a lived experience by library staff. As a result, austerity becomes not just an experience in the present but an expectation for the future. The impact of years of decreasing value of the library experienced through funding cuts and shuttered public libraries permeates the sector and emerges in the interviews in this study.

To offer some perspective on the impact of the pandemic on public libraries, a recent advocacy effort by the American Library Association in support of funding for libraries during the COVID-19 pandemic illustrates the situation public libraries find themselves in during this crisis (Reed \& Levin, 2020). They asked Congress for:

- $\$ 300 \mathrm{M}$ for programming to assist patrons in seeking employment, developing new job skills and starting new businesses.

- $\$ 175 \mathrm{M}$ for digital content to make up for the loss of physical access to libraries

- $\$ 160 \mathrm{M}$ for hot spots to loan out to patrons for working and schooling at home

- $\$ 1.16 \mathrm{~B}$ to project core services in the face of expected cuts

- "With roughly 90 percent of library funding coming from state and local government, ALA anticipates than an average 5 percent cut in budgets will translate into $\$ 582$ million in library cuts, and 10 percent will be $\$ 1.16$ billion.

Clearly, public libraries could benefit from philanthropy. Scholarship on fundraising for public libraries offers models (Lewis, 2018) and new approaches (Garczynski, 2017), but most information supporting fundraising in public libraries is anecdotal or fails to leverage philanthropy research. A review of course offerings in master's programs for library science reveal that while courses on fundraising exist, they are 
rarely offered. At library conferences, audiences for sessions and workshops related to fundraising are routinely small compared to those on other topics. Library directors are simply not trained to fundraise or taught how philanthropy functions in the philanthropic sector. As a critical community asset, the public library has a strong opportunity to leverage philanthropy to support vital community services.

\section{Philanthropy and the Pursuit of Community Well-Being Missions in Mississippi Public Libraries}

The state of Mississippi ranks very low in community well-being (Witters, 2019) but high in philanthropic giving when measured as percentage of income (Fuss \& Palacios, 2019). Therefore, with serious community well-being needs to be met, it is a meaningful place to examine how public libraries are responding to poor community well-being conditions and if philanthropy plays a role in these pursuits and outcomes.

The Mississippi Library Commission (MLC) was founded in 1950 to complete the work of the Federation of Women's Clubs, which was to ensure that each county in the state of Mississippi had its own public library. Its mission today is to leverage leadership training, provide advocacy and offer services to public libraries in the state to "strengthen and enhance libraries and library service for all Mississippians." One of the resources it provides for public libraries in the state is a library trustee handbook. It includes information about charitable donations and suggests two opportunities to fundraise in support of a public library: a library foundation or Friends of the Library group. These groups are required to obtain 501c3 status as determined by both the federal government and the state of Mississippi (Mississippi Library Association, n.d.a, n.d.b, pp. 36-7).

The responsibility of funding public libraries in the state falls to the communities in which it serves (MLC, 2017, p. 33). Oversight of individual public library systems is administered by a board of trustees appointed by local government funders. Most public library systems in the state are supported by a variety of entities as their systems cross city, town, and county lines. (pp. 3-4). Direct funding does not come from the state. However, as a state agency funded through federal funds that come through the Mississippi State Legislature, the MLC can supplement public library funding. This is done through three grant programs and solely in support for personnel, health insurance and life insurance (p. 34). All the public libraries in this study are funded by at least two local government entities and have at least one $501 \mathrm{c} 3$ that supports philanthropic funding.

\section{Interviews with Mississippi Public Library Directors}

Study participants include four public library directors in the state of Mississippi representing four of the five cultural regions in the state. Qualitative data about community well-being missions and philanthropic activities were collected in either a two or three-part series of one-hour interviews. Three interviews were conducted on 
two days approximately one week apart for one hour each. One interview stretched to three hours over the course of three, one-hour sessions.

All the directors brought up the federal budget cuts that are impacting the Mississippi Library Commission, the state agency that supports public libraries (Pettus, 2019). According to recent data, public libraries in Mississippi serve just under three million residents, and over half of state residents live in rural locations. Mississippi has the fourth largest rural population in the country. Only one city in the state, the capital city of Jackson, boasts a population of over 100 thousand. Nearly $20 \%$ of Mississippians live below the poverty line (United States Census Bureau, 2020a, b).

Directors were asked questions on two topics. The first asked them to define the facets of community well-being in their service area that their library supports. Second, they were asked about the impact that philanthropy-related had on their community well-being goals.

The interviews took place following the shelter-in-place guidance across the country. Suspended fundraising when this period began has resulted in a decline in charitable giving (EAB, 2020). In the state of Mississippi, public libraries were forced to close during this time. This created unique challenges for public libraries whose mission is often tied closely to community needs. The suspension of inperson service worried public library directors because their service is most often understood in traditional models and fail to recognize the role of the public library in the digital age. For Mississippi, a state with very low community well-being, high poverty, high unemployment and low-performing schools, services and resources in the public library are integral to education, workforce development, social cohesion, and access to health information.

\section{Mississippi Hills}

This Hills region of Mississippi has the few hills to be found in the state as it presses up against the foothills of the Appalachian Mountains. It is home to the state's most famous celebrities: William Faulkner and Elvis Presley. The University of Mississippi grounds the picturesque town of Oxford. One of the public library directors in this region oversees a system that services two counties. During normal times, the system is visited by five to six hundred people each day.

The director understands the mission of his library system to, "inspire, encourage and promote intellectual advancement in our community." To achieve that, he focuses on access to information and creating a welcome environment. He recently conducted a planning program that developed key indicators that they were achieving this mission. They included responding to service needs, creating young readers, and moving patrons to the online environment.

The public library as a supporter of workforce development is well-known in his community and programs and services related to employment are the most popular service his system supports. An area where he sees a great need but has struggles to get strong participation is information literacy training where patrons are taught how to evaluate online information for value, efficacy, and relevance. He calls the information literacy mission his "moon shot" goal because it is a 
challenge to build interest around it despite it being so crucial to engagement with online information.

Most staff time in his libraries is tied up doing day-to-day activities making it difficult to provide a lot of programming and strategic planning. For example, the main library has a children's librarian, but she is the only staff member in the department. Without any other staff, she spends most of her time responding directly to patron needs and does not have time to plan and conduct some of the programming that would be valuable to youth development and learning. Much of the activity in the libraries in this system is related to computer access. For a region where many families lack technology or access to the Internet, this service is crucial. Broadband is still not widespread in many of the rural communities in the system's service area. The pandemic has brought the need for Internet access and put pressure on the library which has not been open since the shelter-fromhome orders were made in March of 2020. Since then, unable to allow library users into the buildings, the director described seeing students sitting in the parking lot to access the library's free Wi-Fi.

The biggest frustration to meeting the community well-being mission of this library system, according to the director, is that most people do not know what the library has to offer. Connecting to his community of users is a daunting task. He explained the challenge by comparing it to the fact that Coca Cola still advertises to attract people to drink its products. If that level of effort is required to convince people to drink one of the most popular drinks in the world, he explained, "we have a long way to go." When asked what his board sees as the community wellbeing mission of the public libraries, he answered that they are focused most on support for education.

As proud as he is of the number of patrons his library system serves each day, he knows that there are so many more who could benefit from it. Particularly during the time of the pandemic, he recognizes more than ever the need to promote library services and resources. He recently told his board of trustees that despite the outcomes of the next year's budget, more funds will be needed to market the resources and services that support community well-being. He believes that the community would be a better place if more people used it because the library exposes them to different kinds of materials. Due to a resource funded by the Mississippi Library Commission, for example, patrons of any public library have access to collections across the state libraries including the state's public universities.

According to the director, philanthropy at his library exists primarily in the form of volunteerism but further discussion reveals that giving is common. Appointed by city leaders, his volunteer board of trustees are "very supportive." He considers the system to be well funded compared to other library systems in the state. And he feels fortunate that the trustees include former teachers and school administrators who know, firsthand, the value of the library. Even so, they have not been comfortable with the idea of a serious change in their service model during the pandemic. The concern is more about the survival of the library, itself. And though there are opportunities for fundraising, that activity is not conducted by the board. Their role is encouraging city and county funders to support the library. 
This system has both a Friends of the Library group and a library foundation. Each function as an independent $501 \mathrm{c} 3$ focused on supporting the library system. His Friends group has over four hundred members and, like many Friends groups in public libraries, they earn money through a used books store. The bookstore offers meaningful volunteer activities and support relationship-building within the group. The group also holds an annual speaker event funded years ago through a bequest from a former library trustee. Each year, during this event, the Friends leaders solicit cash gifts from the members and other guests to support the library. The library director also asks members to remember the library in their estate. Rather than seen as competition with other cultural events in town, the speaker event has been embraced by the same people who support the local theater and art museum, for example. The director worries that recent momentum towards service and giving will be stalled with the pandemic.

When asked if he keeps a list of expected estate gifts, he replied, "I don't want to know." He does, however, make the case to Friends members that it takes a combination of large and small gifts to enable the library to serve its community. The small gifts are used more for annual expenses, and any planned gifts that come to the library go into an endowment in the library foundation to preserve the future of the library. The current-use funds are primarily the annual membership dues from the Friends group, book sales, and earnings from their annual speaker event. The annual donation from the Friends group typically counts for 2-3\% of the total budget for the system. Most other donations are put into the endowment funds in the foundation. There are several endowments that can be selected to purchase books and equipment or support youth services. They keep donation cards at library check-out desks and have a planned giving brochure to distribute to those interested in that option.

The system has never solicited major gifts, but the director is beginning to have this conversation with his board as they look ahead to an upcoming building project. They are starting to talk about integrating a capital campaign and offering naming opportunities in the new building. He expects that individuals already engaged though the Friends and the annual speaker event will be willing to assist in fundraising at that time. In thinking of the way that philanthropic activity is experienced by the board and volunteers, the director characterizes it as "feeling like we are all in this together." He feels that collective support of the library is community-building and brings positive experiences and emotional benefits to those who participate. He believes that the library is an example of a gift from one generation to the next.

When asked about how philanthropy has impacted the library, he says that the impact has been just as meaningful for those who volunteer and give. He said it gives them a chance to tell their story and for others to hear it. He also believes that making the effort to raise money lets the city and county funders know that he is also helping to fund the library - that it is not all up to them. He feels that they appreciate this effort.

Even though the director identified volunteerism as the primary form of philanthropy in his library system, giving is contributing to community well-being in a variety of ways. It supports events and programming for different groups in the community. Funding to programming supports education, literacy, and entertainment for youth in the community for the most part. The speaker's event is widely popular 
attracting potential donors in town providing them an opportunity to enjoy a social experience and gives the library director the opportunity to ask for philanthropic support. Connections with a large, active, and supportive group of community members elevates the reputation of the library, which is probably why the director reports that he is satisfied with funding from government stakeholders. The likelihood is good that despite the current shut-down of the library itself and outreach activities, once activities resume, the director will have preserved the goodwill created with his users and supporters over the years.

\section{Mississippi Pines}

This Pines region in the southeast portion of the state, gets its name because of the proliferation of longleaf pine trees that cover the area. Historic towns in this region include Columbus and Meridian, which are popular tourist destinations. The region also hosts the state's largest public university, Mississippi State University, in Starkville.

The newly hired library director from one of the systems in the Pines region did not intend to become a librarian. With a music degree and dreams of becoming a professional musician, he took a part-time job in a public library on the recommendation of a friend. After a few years in that role, however, he changed his mind about pursuing a master's degree in music and enrolled in library school. Now in his second role as a library director in the state, he brings the energy and creativity of a gigging musician to his work. Through his experience as a performer, he has an intuitive sense of what his community expects from the library in terms of community well-being. In fact, community engagement is what motivates his passion for librarianship. He was drawn to the library because he recognized it as a crossroads for many community needs. He saw its mission and physical space as an opportunity to make an immediate, tangible impact on community well-being. Through volunteer activities with the American Library Association, he has been trained in methods for leading community conversations. He laments that these programs were not completed before the pandemic and social justice movements in the summer of 2020. However, he sees a real need in his new community to build understanding about the library's value as a community partner.

In addition to the local community, the director also wants to form partnerships with the campus community of the local university. This institution provides tremendous community well-being benefits related to education as well as entertainment and commercial benefits through sports and other campus events. He is pursuing opportunities to connect the public library to networks at the university. In the current health crisis, however, he worries about the consequences of a poorly supported public library with limited staff and resources. His tenure began just weeks before the shelter-from-home order, so his strategies around community engagement were stopped in their tracks. Focused on expanding his community's understanding of the value of the library, he is unable to deliver its most fundamental services. For example, students are in greater need of support during virtual learning than ever before. Like the director in the Hills region, his library serves many families who 
are unable to access the Internet. He wishes he could purchase a WiFi booster to get beyond his small parking lot and provide Internet access to more people during this time, but he lacks the funding to expand those services.

As all public libraries in the state of Mississippi are set up as municipal entities, the director worries about how that limits his ability to fundraise. Up to now, even though his Friends of the Library group raises funds to support the library through book sales, he has not leveraged them as a conduit for processing charitable donations. While the Friends have never denied his requests for funding, they keep tight control over the money they raise, and they have an impressive balance in their bank account. A history of the Friends functioning as a granting unit may make it difficult to transform it into a mechanism for a more widespread fundraising initiative. However, funds provided by the Friends cover the costs for all library programming including the popular summer reading program. Funds from the group also frequently pay for needed items that support library operations. They also host a monthly book talk that enjoys strong participation.

Asked how comfortable the director would be utilizing the Friends for strategic fundraising activities, he feels confident it could work. He trusts the group's current leadership to be open to expanding their role to fundraising. As partners in support of the community well-being mission of the library, he believes the members of the Friends group are integral to meeting this mission. Beyond the crucial funds to deliver education, literacy, and entertainment values for youth in the community and events that provide intellectual and social experiences for adults, the group is also very active in advocacy efforts for the library. Volunteers from the group represent the library at community events throughout the year and offer readings to schools and other local organizations. Some members even support library operations. Even during the pandemic, a core group of volunteers has continued to process paperwork and donations while the library has been closed to the public.

The director is very thoughtful about volunteerism in the library, however, because although requests to volunteer are always well-meaning, they can be a burden on his staff to orchestrate meaningful experiences. With such a small staff, he has not developed robust volunteer programs due to the time and effort required to train and manage these activities. Students from the local university often come to the library to read to children, and that is meaningful on occasion. But he believes that a successful volunteer program requires a coordinator, and he does not have the funding for a new position or the staff capacity to add that to someone's role. He has the same issue regarding a fundraising program but described an innovative solution. He is considering establishing a fund for the library with the local community foundation in order to leverage the assistance of their fundraisers and fund managers for this initiative.

His other major funding group is, of course, the county and local municipalities served by the library system. A recent conversation with members from one of those entities revealed an assumption that primary funding for their local library comes from the state of Mississippi. This governing board was shocked to learn that they were the library's primary funder. The director has also had to provide documentation to show the city's responsibility for facility maintenance and infrastructure expenses at the main branch. Recognizing that this is the result of poor 
communication over the years, he submitted a five-year plan to his government funders. When they saw that their library had over 200,000 visits per year, they were stunned. They had never been told about the impact the library was having in their community. In a discussion with the state senator serving the Pine region at the annual library advocacy event at the state capital, the director learned that the senator thought that the state paid for all the books in the state's public libraries. He was also unaware that a master's degree in library science was a requirement for all library directors.

The director sees himself as an advocate for the library, and he acknowledges that not all directors want to do that kind of work. While many enter into the field of librarianship because they love reading and want to encourage others to read, he is motivated to build a bridge between the library and its community. Years of poor communication from the library he now directs, however, has resulted in poor understanding of the mission and activities at the library with important stakeholders including government funders and potential donors. His community is not aware of the number of individuals who use the library. A self-proclaimed millennial, he sees himself and other directors his age initiating a shift in public library leadership across the country from a mentality of guarding books to leaders connecting communities to what libraries provide and represent. He characterizes the public library as the last public place in America where everyone can achieve a benefit with no expectation of buying anything.

While this library system has delivered community well-being value for generations, the lack of assessments on service and impact has resulted in limited awareness of this value by strategic stakeholders. That is particularly problematic at a time when the library is unable to provide the basic services that they do expect from them. The director is well aware of the need to demonstrate impact when book lending and programming is not possible. Even during the pandemic, he is busy building partnerships with the local schools and preparing impact reports to distribute to government funders. Philanthropy through the library's Friends group has been vital to community well-being missions delivered through programming. There would be no programming in this library system without the funds they earn through their book sales. Through his experience with the American Library Association, he has the tools to build engagement with the Friends that can lead to an expansion of philanthropic activity that supports the library.

\section{Mississippi Delta}

Known as the "Birthplace of the Blues," the Delta region is a popular destination for music fans from across the globe, but it also the region in Mississippi with the highest rate of poverty. Still highly agricultural, this area struggles to achieve widespread employment and strong education outcomes.

The library director at one of the systems in the Delta region came to her role after a career as an elementary school teacher. Education is a major community well-being focus in this area due to its low test scores, rampant unemployment, and poverty. Not surprisingly, the library director is passionate about connecting the 
library to public schools. Her system has five branches that run through the region alongside Highway 49. This is one of the most heavily travelled roads in the state connecting the capital to the Gulf Coast and runs all the way up to northern Arkansas. In the Delta, it travels past the burial place of B.B. King and then partners with Highway 61 to form the legendary spot known as "The Crossroads," which is the legendary site of the birth of the Blues.

In this region, the director explains that her library does a lot with very little. One way she deals with few resources is to empower her staff to come up with creative ideas to meet their community well-being missions. The main one is supporting students. After ten years of attempts by the library system to create a formal partnership with local schools, this director was able to leverage her network to build a program that provides library resources for classroom learning. Because of her familiarity with the learning indicators used to determine student success, she aligned library resources to support those goals. She is currently working to achieve the same partnership for health and literacy initiatives already in place through a grant from the Kellogg Foundation. She knew that the library was an obvious partner to support literacy in the region, but her staff lacks the credentials to deliver literacy training. Innovating with the resources at hand, she created a program where parents are taught to creatively interpret picture books to their children.

The library system in this region also serves a population that lacks widespread broadband, so Internet access is another major element of its community well-being mission. When the pandemic forced the library branches to close, the director could no longer provide this crucial service. She decided to refocus her efforts to providing physical books to people in the community. As a result, her physical collections are circulating at higher rates. In addition to increased circulation among her older patrons, she set up a system for appointments to use library computers and partnered with school librarians to get books to students.

The director is very active in grant-writing and has secured funds to support programming in support of education. She currently has a grant submitted for funds to create a student coding group. She is also very comfortable seeking support through her government funders. Her trustees advocate on behalf of funding for the library, and funding to the library has increased. She also has a Friends group that supports the main branch. When it comes to fundraising, however, she does not participate. She considers it illegal for her or her staff to support fundraising in any way. The funds raised by the Friends group supports programming like the annual Easter egg hunt. The Friends also facilitate other events intended to bring people into the library and learn about library resources and services. They have hosted their own fundraisers and written grants on behalf of the library as well.

As a result of her career as an elementary school teacher, this director is more aware than others in the study about the potential of the public library to help meet critical community well-being goals, particularly those related to student learning. She is also adept at identifying funding opportunities through government funders and partnering with national foundations to help deliver on well-being missions. Her caution around philanthropic activity is not about discomfort. Instead, she worries that integrating private support could put her government funding at risk. However, philanthropy is helping her meet her community well-being goals, none-the-less. 
Her Friends group is educating the community about the library and building affinity through programming and purchases that enhance the user experience in the branches. Her trustees, as well, are advocating to government funders resulting in increased funding for the library.

\section{Mississippi Capital/River Region}

The Capital/River region of the state is known for its antebellum architecture featured most notably in the historic cities of Natchez and Port Gibson. Vicksburg is the site of a famous Civil War battle and Jackson, the state capital, is the largest city in the state with a wide variety of cultural organizations including museums and performing arts centers. It is also home to the medical school of the University of Mississippi, Jackson State University, Belhaven University, Tougaloo College and Millsaps College.

South of Jackson, in a library system serving a rural population, the library director defines her community well-being mission in a traditional public library frame. Providing resources, primarily in the form of books, and technology that supports lifelong learning are her primary community well-being goals. Many in her region also lack access to the Internet, so most people who come into her two branch libraries do so to get online. Young people use Internet-enabled computers for gaming and social media activity whereas adults look for jobs, take online classes, or submit paperwork for social and government services.

In terms of community well-being, the director's dream is for the library to be a recreation destination for her community that includes both physical and virtual engagement. She thinks these entertainment values for community members would surprise city and county funders. Her happiest moments in the library are seeing children going through the stacks and people relaxing in chairs with a book. She would love to be able to support some of the niche interests in her community like the local cosplay community. For now, she thinks that government funders value the library as an institution that is part of the kind of infrastructure that makes people think that their community is legitimate, but they do not truly understand what the library does or can do.

Thankfully, her board of trustees actively advocates for the library to government funders though their concept of the value of the library is also limited. Few, for example, appreciate the impact of providing technology or understand how people use it. While they may appreciate the library, they do not know what it means to really need it. For the individuals in her community who do need the library, she believes that it provides a hope for bettering themselves. Any threat to the library's ability to support that hope, she feels, undermines that opportunity. Unfortunately, many who she thinks could benefit from its services do not participate. Events focused on Black History and featuring collections that represent the various racial and cultural communities in her service area have helped bring more groups into the library, but the lack of familiarity with navigating resources and spaces makes it difficult for many to integrate the library into their regular activities. When we spoke, she was thinking about creating a video of 
how to use the library in the hope that it could help mitigate fears or discomfort about coming in.

She is focused on capacity-building in the library to prepare for future partnerships that support virtual K12 education and public health. When I spoke to her during the pandemic, she was preparing to submit a grant to expand her computer lab to support online school and other increasing demands for technology. With a very limited staff, many of which are in a high-risk health category, she does not feel confident that she can deliver on promises of a partnership yet with area schools and health providers. The library's designation as a municipal organization also challenges partnershipbuilding. Engagement policies for tax-payer-supported organizations do not give her the same flexibility as nonprofit organizations, so she is cautious about setting expectations around mutual benefits for partnering.

Like other library directors in the study, she is very focused on her responsibility to the community but not comfortable with the idea of the community having a responsibility for the library. Selfish motivations of funders who could get the library off track of its mission is a minor concern, but she also feels responsible for demonstrating that the library is not making a profit. Austerity as a virtue is common in libraries and across the philanthropic sector. Therefore, grants are more of a comfort zone for her than working with individual donors. Overall, there is a fundamental concern that engaging in efforts to build philanthropic giving could affect the libraries' core mission.

However, her library does have an active Friends group which donates around two thousand dollars a year from their book sale program. They also collect items and other donations contributing a total of five to seven thousand dollars a year in money and resources. Most of their support is directed towards programming for children including infrastructure to support that programming like bookshelves, eBooks, televisions, and event supplies. She takes special care on how she requests and receives support to ensure that she maintains regulations related to acceptance of donations. Asked what she would do if someone came to the library and made a cash donation, she acknowledges that small donations are not uncommon. Depending on the situation, she either accepts them for a discretionary fund or gives them to the Friends group to process.

The more we talked about donations, the more this activity was revealed. Library trustees, for example, solicit gifts to meet matching requirements for grants, and the library receives memorial gifts for book purchases. Also, the three advisory boards representing the branches in her system regularly solicit support for their branches from individuals and businesses. This collective giving supports programming in the branches. She has asked her Friends group to investigate corporate memberships and would use a large bequest to fund a bookmobile. Even with concerns, she understands the potential of philanthropy to meet her community well-being missions.

\section{Conclusion}

Philanthropy means something different depending on its application. It is a theory, process and sometimes an outcome. In this study, philanthropy is examined as a process. Specifically, it is a mechanism in the form of fundraising that allows public libraries featured in this study to meet their community well-being missions. 
Fundraising is an issue of much discussion and concern in the library sector mostly due to the decline in giving in recent years (Bracken et al. n.d.). In this study, it was a distressing topic for public library directors. This was not a surprise as discomfort with philanthropy is a common condition that creates a sense of austerity in the sector. Hitchen's (2019) study of public libraries in Northern England, describes this phenomenon as social geography. The persistence of a narrative of austerity and lack among library leaders and staff exacerbates the feeling of being undervalued by those that libraries serve and depend upon for support and transform it into a lived experience. This condition is one explanation for why the library directors in this study sometimes failed to recognize the level to which philanthropy is active in facilitating community well-being initiatives in their library.

Other barriers to fully embracing philanthropy as a vehicle to facilitating community well-being missions is confusion about what qualifies as philanthropy. At a time when extremely large donations are reported widely, small donations at the library book check-out counter and ticket purchases to annual events may not be appreciated as philanthropy. Terms like philanthropy, charity, and fundraising are often confused and may represent different activities or giving levels to different people. Other factors that emerged in the interviews revealed a lack of understanding about how aligned 501c3 organizations routinely support public and governmental organizations. This is a common scenario for public universities and hospitals, for example. The library directors featured in this study demonstrated a lack of familiarity with the role of affiliated nonprofit organization to supplement government funding even when they reported that they had affiliated $501 \mathrm{c} 3$ organizations like Friends of Library groups and library foundations.

Public libraries desperately need funding that private citizens might be happy to give were they asked and provided the mechanism to do so. Support from individual donors is crucial to innovation and community response in public libraries and other community and philanthropic organizations. In the current climate of the pandemic and social unrest, individuals want to help meet philanthropic missions. It is a missed opportunity for public libraries to resist fundraising when many are looking for ways to help support and build community well-being.

Interviews in this study revealed that despite claims that fundraising had a limited role in meeting community well-being goals, discussions about donor engagement proved otherwise. Future research that collects giving data rather than self-reports of fundraising activity could determine the true level and impact of philanthropic activity in public libraries. Like the library directors in this study, further research may reveal that the social geography created by decades of austerity in the library sector is a barrier to recognizing philanthropy when it occurs.

\section{Declarations}

Not applicable

Conflict of Interest On behalf of all authors, the corresponding author states that there is no conflict of interest. 


\section{References}

Aabo, S. (2005). The role and value of public libraries in the age of digital technologies. Journal of Librarianship and Information Science, 37(4), 205-211.

Albanese, A. (2020). "Are public libraries in Decline?" https://www.publishersweekly.com/pw/by-topic/ industry-news/libraries/article/82925-are-public-libraries-in-decline.html\#: :text=Yes\%2C\% 20the\%20Gallup\%20poll\%20reports,libraries\%2010.5\%20times\%20a\%20year.\&text=And\%20the $\%$ 20IMLS\%20data\%2C\%20published,for\%20the\%20past\%20seven\%20years.

American Library Association (1876). 'Mission of organization.' Organization founding. October 6, 1876, Philadelphia, PA.

American Library Association (1892). Mission. https://www.ala.org/aboutala/missionpriorities

American Library Association (2015). American Library Association strategic directions. http://www. ala.org/aboutala/sites/ala.org.aboutala/files/content/governance/StrategicPlan/Strategic\%20Directio ns\%202017_Update.pdf.

Andreoni, J., \& Payne, A. A. (2003). Do government grants to private charities crowd out giving or fundraising? American Economic Review, 93(3), 792-812.

Aquinas, S. T. (1225-1274). The "Summa Theologica” of St. Thomas Aquinas. Oates \& Washburn, ltd.

Aristotle, \& Irwin, T. (1999). Nicomachean ethics (2nd ed). Hackett Publishing Company, Inc.

Bartlett, J. A. (2018). New and noteworthy: Philanthropy and libraries. Library Leadership \& Management, 32(3), 1-4.

Bertot, J. C., McClure, C. R., \& Jaeger, T. (2008). The impacts of free public internet access on public library patrons and communities. Library Quarterly, 78(3), 285-301.

Bracken, J., Frick, R., Cohen, D., \& Gerstenhaber, K. (n.d.). Visualizing funding for libraries. Retrieved March 13, 2021, from https://libraries.foundationcenter.org/.

Brest, P. (2012) A decade of outcome-oriented philanthropy. Stanford Social Innovation Review. https:// ssir.org/articles/entry/a_decade_of_outcome_oriented_philanthropy\#: :text=\%E2\%80\%9COut come\%2Doriented\%E2\% $80 \% 9 \mathrm{D} \% 20$ is \%20synonymous, monitor\%20progress $\% 20$ toward\%20ut comes\%20and.

Carter, T. G., Chandler, J., Cohen, R., Delaney, T., Higgins, A., O’Leary, A. S., \& Thompson, D. L. (2019). Nonprofit impact matters. National Council of Nonprofits. https://www.nonprofitimpact matters.org/site/assets/files/1/nonprofit-impact-matters-sept-2019-1.pdf.

D'Elia, G., Jorgensen, C., Woelfel, J., \& Rodger, E. J. (2002). The impact of the Internet on public library use: An analysis of the current consumer market for library and Internet services. Journal of the American Society for Information Science and Technology, 53(10), 802-820.

EAB (2020). EAB survey points to dramatic decline in university fundraising: Decline in donations could exceed drop experienced during the Great Recession [Press release]. June 8.

EveryLibrary (2020). EveryLibrary statement on proposed cut to IMLS [Press release], February 10. https://www.everylibrary.org/prsaveimls.

Fuss, J., \& Palacios, M. (2019). Generosity in Canada and the United States: The 2019 generosity index. Fraser Research. https://www.fraserinstitute.org/sites/default/files/generosity-index-2019.pdf.

Garczynski, J. (2017). Fundraising: How to raise money for your library using social media. Chandos Publishing.

Giving USA (2020). Giving USA 2020: Charitable giving showed solid growth, climbing to \$449.64 billion in 2019, one of the highest years for giving on record. Giving USA. https://givingusa.org/ giving-usa-2020-charitable-giving-showed-solid-growth-climbing-to-449-64-billion-in-2019-oneof-the-highest-years-for-giving-on-record/.

Gross, R. A. (2002). Giving in America: From charity to philanthropy. In L. J. Friedman \& M. D. McGarvie (Eds), Charity, philanthropy, and civility in American history (pp. 29-48). Cambridge University Press.

Hall, P. D. (1992). Inventing the nonprofit sector. The Johns Hopkins University Press.

Hitchen, E. (2019). The affective life of authority: Uncanny atmospheres temporalities. Social Cultural Geography.

Institute of Museum and Library Services (IMLS) (2020). People visited public libraries more than a billion times on one year [Press release], July 16. https://www.imls.gov/news/people-visited-publiclibraries-more-billion-times-one-year.

Jaeger, P. T., \& Fleischmann, K. R. (2007). Public libraries, values, trust, and E-government. Information Technology and Libraries, 26(4), 35-43. 
Jaros, E. (2019). Measures that matter: IMLS, COSLA to explore link between public libraries, workforce development, and community wellbeing [Press release]. September 9. www.imls.gov/news/measu res-matter-imls-cosla-explore-link-between-public-libraries-workforce-development-and.

Kerslake, E., \& Kinnel, M. (1997). The social impact of public libraries: A literary review. Boston Spa: British Library Innovation Centre (Report No. 85).

Lewis, V. (2018). 15 models for library advancement. In D. Koen, \& T. E. Lesneski (Eds), Library Design for the $21^{\text {st }}$ Century: Collaborative Strategies to Ensure Success (pp.214-220). Walter de Gruyter GmbH \& Co.

Mississippi Library Commission (2017). Mississippi trustee handbook. https://mlc.lib.ms.us/wp-content/ uploads/2015/04/FINAL-DRAFT-Trustee-Handbook-2017-091217.pdf.

Mississippi Library Commission (n.d.a). A brief history of Mississippi libraries. In Director's Resource Guide. https://directorguide.lib.ms.us/a-brief-history-of-mississippi-libraries/.

Mississippi Library Commission (n.d.b). https://mlc.lib.ms.us/.

National Public Radio (2013). For you to borrow, some libraries have to go begging. From the series Keys to the whole world, American public libraries. https:/www.npr.org/2013/08/19/209903975/for-youto-borrow-some-libraries-have-to-go-begging.

Payton, R. L. (1988). Philanthropy: Voluntary action for the public good. Collier Macmillan Publishers.

Pettus, E. W. (2019). Analysis: Budget cuts have long-term effects on libraries. The Washington Times. https://www.washingtontimes.com/news/2019/feb/3/analysis-budget-cuts-have-long-term-effect-onlibr/?utm_source=GOOGLE\&utm_medium=cpc\&utm_id=newsroom\&utm_campaign=TWT +-+ DSA\&gclid=CjwKCAjw4rf6BRAvEiwAn2Q76vPmsu58nkYf_9tCYYTykyYUMgjCYrylo HdQYUj3fT54kbNzaO95lhoC6KkQAvD_BwE.

Reed, J., \& Levin, A. (2020). Library Stabilization Fund Act (S.4181/H.R.7486). http://www.ala.org/ advocacy/sites/ala.org.advocacy/files/content/libfunding/LSFA_Summary_Final.pdf.

Schatteman, A., \& Bingle, B. (2015). Philanthropy supporting government: An analysis of local library funding. Journal of Public and Nonprofit Affairs, 1(2), 74-86.

Tkacik, K. (2017). Finding philanthropic funding: Back talk. Library Journal. https://www.libraryjou rnal.com/?detailStory=finding-philanthropic-funding-backtalk.

United States Census Bureau (2020a). 2019 American Community Survey Statistics for Income, Poverty and Health Insurance available for States and local areas. https://data.census.gov/cedsci/.

United States Census Bureau (2020b). Mississippi Population 2020. https://www.census.gov/quickfacts/ MS.

Witters, D. (2019). Hawaii tops U.S. in wellbeing for record $7^{\text {th }}$ time [Press release], Gallup, February 27. https://news.gallup.com/poll/247034/hawaii-tops-well-being-record-7th-time.aspx.

Zunz, O. (2012). Philanthropy in America: A history. Princeton University Press.

Publisher's Note Springer Nature remains neutral with regard to jurisdictional claims in published maps and institutional affiliations. 